\title{
‘Harley Davidson' Success Speaks- Brand Image and Culture: An HR Perspective
}

\author{
Dr. Kishore Kumar Das and Aftab Ara
}

\begin{abstract}
Technology is the cause of shift in HR to go beyond mere administrative support functions to fruitful strategies for success. HR strategies decide whether market share, sales, or profits would increase or not. The key result areas in people management shows shift from production and quantity to productivity and quality. Capability is measured in ideas generated by employees to be implemented, since productivity gained is of more prominence than capacity measured in man-hours lost, man-hours available, absenteeism, etc. Success achieved in business has its own challenges. William M. Harley in 1901, created his own bluechip of the engine to fit in a bicycle. Since then his journey was transformed from a small business to a business tycoon as the manufacturer of Motorcycles along with genuine HarleyDavidson parts, accessories and collectibles. Harley Davidson Inc became headquarter of his group of companies as Harley-Davidson Motor Company (HDMC) and HarleyDavidson Financial Services (HDFS) in USA after being founded in 1903. The company has a strategic position in marketplace with his valued customers who are extremely satisfied with the global standard image and brand. Even after having such huge success it faced challenges from lower priced competitors and was unable to expand into overseas markets. Accenture helped Harley-Davidson in improving its business strategies to meet the challenges at such troubled times. This study aims to find the popularity of its brand, image and culture of H-D which has helped in success of the Motorcycle Industry. It also aims to study the gaps in culture that needs to be improved. The purpose of the article is to study the case of $H-D$ and recommend certain strategies to be brought by HR in bringing changes in the organization. The methodology of study is by collecting the primary and secondary data.. Interviews of employees are conducted and on-line surveys were taken. The findings provide an opportunity for other well -to-do world class companies to have a look into their systems and recognize their deficit in strategies which is preventing them to move forward with speed in such a fast paced world of today.
\end{abstract}

Keywords--- HR Strategies, Brand, Image, Organizational Culture, Competency Development

\footnotetext{
Dr. Kishore Kumar Das, Head, Department of Commerce and Management, Ravenshaw University, Cuttack, Odisha, India. Email:hodcommerceru1@gmail.com

Aftab Ara, Research Scholar in Management, Ravenshaw University, Cuttack, Odisha, India.E-mail: ara.aftab@gmail.com
}

DOI: 10.9756/BIJIEMS.4808

\section{INTRODUCTION}

$\mathrm{T}$ ECHNOLOGY causes shift in HR to go beyond mere administrative support functions to fruitful strategies for success. HR strategies decide whether market share, sales, or profits would increase or not. The key result areas in people management shows shift from production and quantity to productivity and quality. Capability is measured in ideas generated by employees to be implemented, since productivity gained is of more prominence than capacity measured in manhours lost, man-hours available, absenteeism, etc. Success achieved in business has its own challenges. William M. Harley in 1901, created his own blue-chip of the engine to fit in a bicycle. Since then his journey was transformed from a small business to a business tycoon as the manufacturer of Motorcycles along with genuine Harley-Davidson parts, accessories and collectibles. Harley -Davidson Inc became headquarter of his group of companies as Harley-Davidson Motor Company (HDMC) and Harley-Davidson Financial Services (HDFS) in USA after being founded in 1903.

Harley Davidson is the worldwide producer of motorbikes, known by its brand, style, strength, freedom, individuality and independence. Since 1903 it has produced world class bikes which has not been done by anyone .In addition to motorbikes it produces a complete line of Genuine Motorcycle Parts \& Accessories, apparel and branded merchandise and offers our riders thousands of custom, personalized options for their bikes .Having celebrated its $100^{\text {th }}$ anniversary as a company it earns a name for the quality of its product and customer loyalty enjoying $98 \%$ customer retention rate .The workforce feels pride in working at Harley-Davidson .There is an internal recruitment of employers from the friends and families at HD thus contributing to the addition of workforce The company has a strategic position in marketplace with his valued customers who are extremely satisfied with the global standard image and brand.

Even after having such huge success it faced challenges from lower priced competitors and was unable to expand into overseas markets. Accenture helped Harley -Davidson in improving its business strategies to meet the challenges at such troubled times. This study aims to find the popularity of its brand, image and culture of H-D which has helped in success of the Motorcycle Industry .It also aims to study the gaps in culture that needs to be improved. The purpose of the article is to study the case of H-D and recommend certain strategies to be brought by HR in bringing changes in the organization. We reviewed relevant secondary literature to understand existing Strategic role of HR practices. We also conducted interviews with employees and customers - inside and outside of Harley-Davidson - who have worked with 
companies on HR transformation efforts. The findings provide an opportunity for other well -to-do world class companies to have a look into their systems and recognize their deficit in strategies which is preventing them to move forward with speed in such a fast paced world of today.

\section{REVIEW OF LITERATURE}

HRM is chiefly responsible for recruiting, selection, training, assessment, rewarding and giving benefits to the organization with control over the organizational culture, leadership and at the same time abiding with the employment and labor laws .HR acts as a primary interpreter between the company and his employees. Human Relations movement gave form to HR in the $20^{\text {th }}$ Century when the researchers thought of strategic management of the workforce. In those times the HR's main work was mostly transactional like payroll and benefits administration. Presently due to globalization, technological advancement and cut throat competition worldwide it is taking strategic initiatives like mergers and acquisition, succession planning, talent management, labor relations, diversity, inclusion.

In the early $20^{\text {th }}$ century Frederick Taylor coined the term" scientific management "also known as Taylorism with an effort to improve the economic efficiency in manufacturing jobs. He thus put labor as the key input for manufacturing. Elton Mayo's Hawthorne studies brought forth a clear picture that financial compensations and working conditions lead to more enthusiastic workers leading to higher productivity. The contemporary work by Abraham Maslow, Kurt Lewin, Max Weber, Frederick Herzberg, and David McClelland gave the foundation of organizational behavior and organizational theory. Andrew Carnegie John Rockefeller made hypothesis for strategic workforce management. The employee-employer relationship took form as industrial and labor relations by a là Sidney and Beatrice Webb, Franklin D. Roosevelt and the New Deal.

The Chartered Institute of Personnel and Development was founded in England as the Welfare Workers' Association, which later became the Institute of Industrial Welfare Workers after a decade and again to Institute of Labor Management .Cornell University in 1945, was set up as the world's first institution of higher education, dedicated to workplace studies as the School of Industrial and Labor Relations

During the latter half of the 20th century, as the workforce management expanded and influenced whereas the union membership declined significantly, the" Industrial and labor relations" were used to refer to issues relating to collective representation, and the companies refereed to the profession as "personnel administration".

In 1948, the Society for Human Resource Management (SHRM) — was founded as the American Society for Personnel Administration (ASPA) which later became the largest HR association in the world. In the $21^{\text {st }}$ century with the increased communication and transportation there was an increase in workforce mobility .Companies now viewed employees as assets and not just machines for doing
work."Human Resource Management was the dominant term for function and its name was changed to SHRM in 1998. Human Capital management is used with HR.

The strategic management discipline originated in the 1950s and 1960s.Alfred Chandler recognized the importance of coordinating management activity under an allencompassing strategy. Interactions between functions were typically handled by managers who relayed information back and forth between departments. Chandler stressed the importance of taking a long term perspective when looking to the future. In his 1962 ground breaking work Strategy and Structure, Chandler showed that a long-term coordinated strategy was necessary to give a company structure, direction and focus. He says it concisely, "structure follows strategy."

In 1957, Philip Selznick formalized the idea of matching the organization's internal factors with external environmental circumstances. This core idea was developed into what we now call SWOT analysis by Learned, Kenneth R. Andrews, and others at the Harvard Business School Genera Management Group. Strengths and weaknesses of the firm are assessed in light of the opportunities and threats in the business environment.

Igor Ansoff built on Chandler's work by adding concepts and inventing a vocabulary. He developed a grid that compared strategies for market penetration, product development, market development and horizontal and vertical integration and diversification. He felt that management could use the grid to systematically prepare for the future. In his 1965 classic Corporate Strategy, he developed a gap analysis to clarify the gap between the current reality and the goals and to develop what he called "gap reducing actions".

Peter Drucker was a prolific strategy theorist, author of dozens of management books, with a career spanning five decades. He stressed the value of managing by targeting welldefined objectives. This evolved into his theory of management by objectives (MBO). According to Drucker, the procedure of setting objectives and monitoring progress towards them should permeate the entire organization.

Strategy theorist Michael Porter argued that strategy target either cost leadership, differentiation, or focus. These are known as Porter's three generic strategies and can be applied to any size or form of business. Porter claimed that a company must only choose one of the three or risk that the business would waste precious resources. W. Chan Kim and Renée Mauborgne countered that an organization can achieve high growth and profits by creating a Blue Ocean Strategy that breaks the trade off by pursuing both differentiation and low cost.

In 1985, Ellen-Earle Chaffee summarized what she thought were the main elements of strategic management theory by the 1970s .

Strategic management involves adapting the organization to its business environment.

- Strategic management is fluid and complex. Change creates novel combinations of circumstances requiring unstructured non-repetitive responses. 
- Strategic management affects the entire organization by providing direction.

- Strategic management involves both strategy formation (she called it content) and also strategy implementation (she called it process).

- Strategic management is partially planned and partially unplanned.

- Strategic management is done at several levels: overall corporate strategy, and individual business strategies.

- Strategic management involves both conceptual and analytical thought processes.

Edith Penrose's work in the late 1950s, the resource-based view was largely introduced to the field of strategic management in the 1980s and became a dominant framework in the 1990s

\section{A. Organizational Performance}

Organization performance has been the most important issue for every organization be it profit or non-profit. Researchers among themselves have different opinions and definitions of performance, which remains to be a contentious issue among organizational researcher [1]. The central issue concerns with the appropriateness of various approaches to the concept utilization and measurement of organizational performance [2]. Performance is equivalent to the famous 3Es (economy, efficiency, and effectiveness)[3].Performance measures could include result-oriented behavior (criterionbased) and relative (normative) measures, education and training, concepts and instruments, including management development and leadership training, which were the necessary building skills and attitudes of performance management. Hence, from the above literature review, the term "performance" should be broader based which include effectiveness, efficiency, economy, quality, consistency behavior and normative measures [4].

Organizational model of firm performance focused on organizational factors such as human resources policies, organizational culture, and organizational climate and leadership styles. Another study found that [5] there were five major factors determining organizational performance, namely:

- Leadership styles and environment,

- Organizational culture

- Job design

- Model of motive, and

- Human resource policies

\section{B. Corporate Branding}

It was in the mid-nineties that branding literature emerged. Businesses began shifting their focus from product brands to corporate branding [6]. A corporate brand as a brand that represents an organization and reflects its heritage, values, culture, people, and strategy[7].Corporate branding congruent with the strategic brand vision dwells on developing brands at an organizational level[8].A corporate brand is defined primarily by organizational associations and thus can develop and leverage organizational characteristics, as well as product and service attributes [9].The distinguishing six differences between product and corporate branding[10]. They are-

- The shift in focus from product to corporation of the branding effort;

- The different exposure the organization is subject to, which makes the firm's behavior and its interaction with society much more visible;

- The relation of the brand to all company stakeholders, not just customers;

- The requirement of organization-wide support;

- The temporal dimension of corporate brands includes past and future, not just present

- The greater reach of corporate brands than product brands means that they take on more strategic importance.

A Corporate branding is based on three elements -Vision, Organizational Culture and corporate image.

Vision is the decision made by the top management such as the lines of business, locations, partners and alliance, change initiatives and corporate symbolism.

Culture is the decisions made by the organizational members such as working hard ,seeking challenge, being loyal and taking organization to the positive side of success.

Image is made by the external stakeholders such as buying products and services, seeking employment, praising or criticize company, investing in company or seeking to regulate the company.

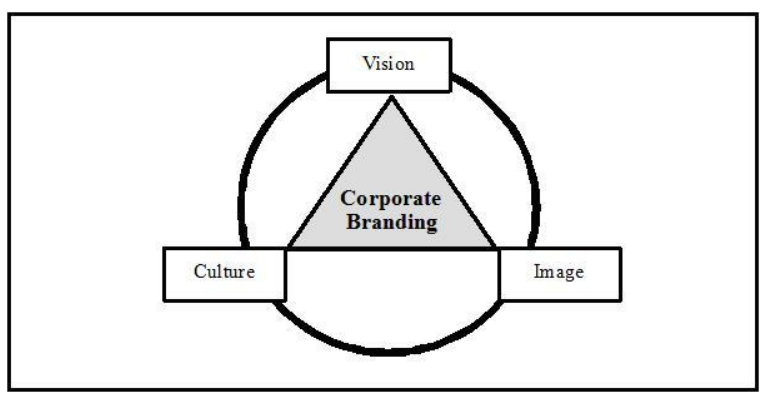

Figure: 1: Corporate Branding Image Hatch and Schultz 2003

\section{Organizational Culture}

Organizational culture has been characterized by many authors as something to do with people and the unique quality and style of the organization [11], and the way things are done in the organizations [12]. Sometimes, organization culture is also known as "corporate culture". "Corporate Culture" is used to denote the more "commercialized" meaning of organizational culture[12]. The collective programming of the mind that distinguishes the members of one organization from another. This included shared beliefs, values and practices that distinguished one organization to another [13]. Set of symbols, ceremonies and myths that communicate the underlying values and beliefs of the organization to its employees [14] Three component systems: context or core values, forms (process of communication, e.g jargon), strategies to reinforce content (e.g. ,rewards, training programs)[15]. 
a. Refers to something that shared by all or almost all members of some social groups[16]

b. something that the older members of the group try to pass on to the younger members and[16]

c. something that shapes behaviour or structures one's perception of the[16].

The underlying values, beliefs and principles that serve as a foundation for an organization's management system as well as the set of management practices and behaviors that both exemplify and reinforce those basic principles[17]. What is valued, the dominant leadership styles, the language success that make an organization unique[18].

\section{OBJECTIVES OF THE STUDY}

The objectives of the study are-

- Gauge popularity of H-D brand image by customers.

- Establishing correlation between the work culture and growth of the company.

- Find the importance of employee's recognition by the Top Management.

\section{SETTING UP OF HyPOTHESIS}

The study aims at the following hypothesis

- Harley Davidson has its own brand image.

- Friendly work culture helps in the company's growth.

- Employee's recognition is essential by the Top Management.

\section{RESEARCH METHODOLOGY}

The research methodology was -

- To understand the organization.

- To gauge the popularity of H-D by its brand Image

- To evaluate the work culture helping in the growth of the organization.

- Importance of employee's recognition by top management.

The tools and techniques used were- interview, online survey and questionnaire

The sources of data were:

- Primary Data was collected by interview, online survey and questionnaire

- Secondary Data was collected by journals, internet, magazines, newspapers etc

The respondents were the sampling units through which data was collected. These were the employees of Harley Davidson. There were 139 employees and the sample of study was taken as Harley Davidson Inc. with the period of this study from 3-4 years..

\section{HARLEY-DAVIDSON: AN OVERVIEW}

Harley-Davidson Inc formerly known as HD is H-D in abbreviation or Harley is an American motorcycle manufacturer. Founded in Milwaukee, Wisconsin, during the first decade of the 20th century, it was one of two major American motorcycle manufacturers to survive the Great
Depression. Harley-Davidson also survived a period of poor quality control and competition from the Japanese manufacturers.

In brief

- In 1903, William S. Harley \& William, Arthur, Walter Davidson made Harley Davidson.

- In 1909, the First V-twin powered bikes became most enduring icons of Harley Davidson history in 1917.

- $1 / 3 \mathrm{rd}$ of the bikes were sold to the U.S military, at least 20,000 HD bikes were used in World War I (1918).

- In $1922 \mathrm{HD}$ dealerships spread across 74 countries. In 1933 there was an art deco "Eagle" is printed on tanks this started the graphic design on HD.

- 1953 saw the new attractive $\operatorname{logo}$ created for $50^{\text {th }}$ anniversary with caption "50 years-American made".

- Between the years 1983-1986, H-D entered into American \& New York stock exchanges.

- In 1997 two big plants were constructed in Milwaukee \& Kansas cities.

- In 2002 there was an "Open Road Tour" debuted in Atlanta to celebrating $100^{\text {th }}$ Anniversary.

- The demand for heavy weight motor cycle in U.S surged by $17 \%$ compared to IGR of $10 \%$. In 2003 there were more than 950,000 bikes were sold in U.S \& 28 million worldwide expected to grow 5\% every year. HD thus recorded its $19^{\text {th }}$ consecutive year of record earnings in 2004. Harley is known to be the only major American Manufacturer of heavy weight motor cycle having more than 15,000 employees.

- In August 2009, Harley-Davidson planned to enter the market in India, and started selling motorcycles in 2010. The company established a subsidiary, HarleyDavidson India, in Gurgaon, near Delhi, in 2011, and created an Indian dealer network

- The main features Harley Davidson is Softail Family for example narrow seats, tombstone tail lights, full length floor boards Harley Davidson Sportster Family e.g.: low-rise handlebars, bullet style head light. Harley Davidson Touring (Dressers) Family large windshield \& have a full front fairing, leather saddlebags, optional sidecar, \& option to customize, engines Big V-twins, Small V-twins and the Revolution engine

- The Main figures in 2009 is HD's share of the U.S. heavyweight $(651+\mathrm{cc})$ market was $53 \%$ \& $12 \%$ in Europe. (app.) Capital Expenditures were $\$ 116.7$ million in $2009 \& \$ 1.0$ billion in the last 5 years. $\$ 100$ invested in Harley-Davidson at the end of 1986 would be worth approximately $\$ 9,000$ at the end of 2009 . The Company incurred $R \& D$ expenses of $\$ 143.1$ million, \$163.5 million and \$185.5 million during 2009, 2008 \& 2007 respectively.

- Values of HD: Values are the heart of HD business, they guide our action and serve as the framework for the decisions and contribution of our employees make at every level of the company." Tell the truth Be fair 
Keep your promises Respect the individual Encourage Intellectual curiosity".

- Product Extensions :Motor Cycles Bike accessories Buell motor cycles: wholly owned subsidiary of Harley by 2003 which is now closed .

- Brand extensions Merchandise Helmet Clothes (Jackets...) Mugs Collectibles.... Beer Bars

\section{LIMITATIONS OF THE STUDY}

Though it has been tried to make a detailed analysis on Strategic role of HR at Harley Davidson, still the study suffers from certain limitation.

- Due to the constraint of not revealing the company's policy, the organization was reluctant in sharing their information for the fulfillment of the study.

- As the employees were so busy, it was too difficult for them to give some time for the study and some working employees hesitated to give their own opinions.

- There was time constraint.

- Sample for survey was not enough.

\section{ANALYSIS OF THE VARIABLES}

From the above discussion a study was conducted for the employees of Harley Davidson by an online questionnaire regarding the work culture helping in the company's growth, recognition of the employee's by the Top Management and involvement of Management for the innovation of new products. Some of the variables are analyzed as follows:

\section{A. Analysis of Brand Image of the Product \\ a. Does Harley Davidson create a Brand Image of its own?}

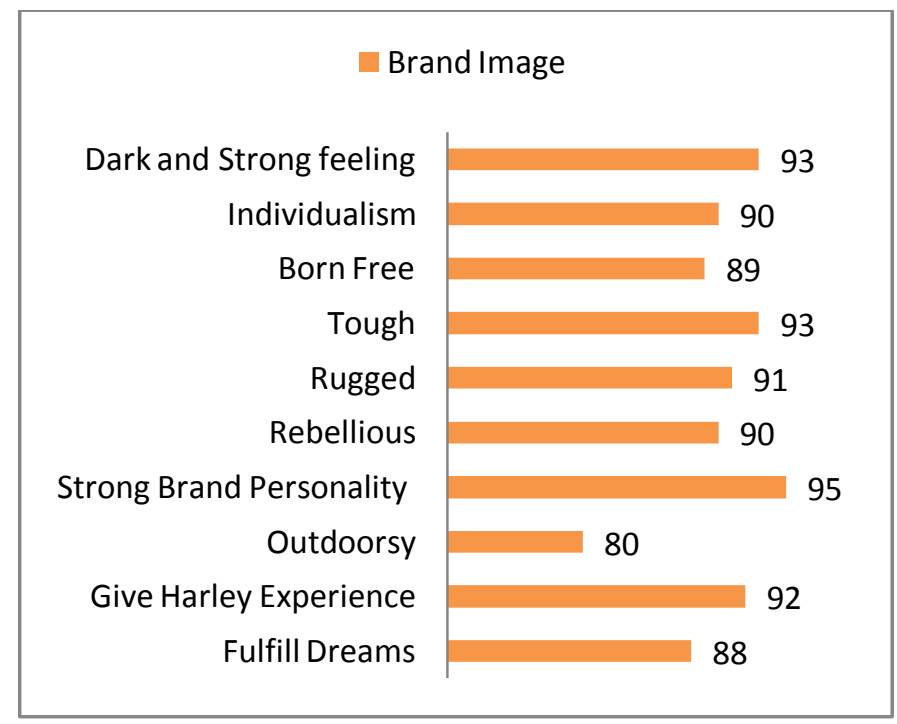

Figure 2: Brand Image of H-D

Sources: Compiled from survey of H-D respondents Interpretation: According to the survey of data we found that $95 \%$ responded that the company has strong brand personality, 93\% responded it is tough, dark and strong feeling ,92\% responded that the products gave a feeling of Harley experience, $91 \%$ responded that the product gave a rugged appearance, $90 \%$ responded as giving the feeling of being rebellious and individual ,89\% responded it made them feel born free, $88 \%$ responded that it fulfills dreams and $80 \%$ response that it is outdoorsy.

\section{B. Analysis of Organization Culture}

\section{a. Prevailing Working Environment in the Organization}

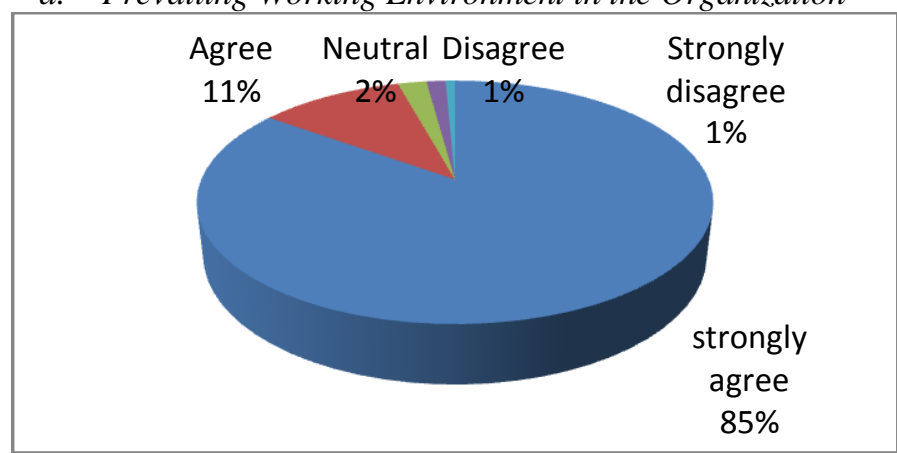

Figure 3: Friendly Working Environment

Sources: Compiled from survey of H-D respondents

Interpretation: According to the sample selected we can deduce from the above pie chart that the majority of employees at Harley Davidson comprising of $84.89 \%$ found the working environment to be very friendly

b. Prevailing Environment is a Challenging Place to Work

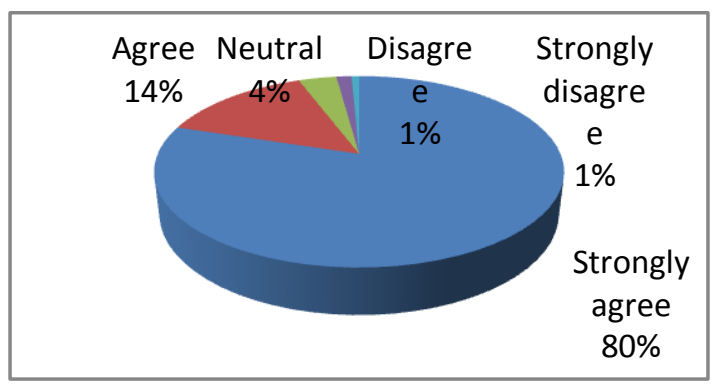

Figure 4: Prevailing Working Environment

Sources: Compiled from survey of H-D respondents

Interpretation: According to the sample studied $79.85 \%$ of the employees feel that the environment is a challenging place to work.

c. Is the Company a Great Place to work?

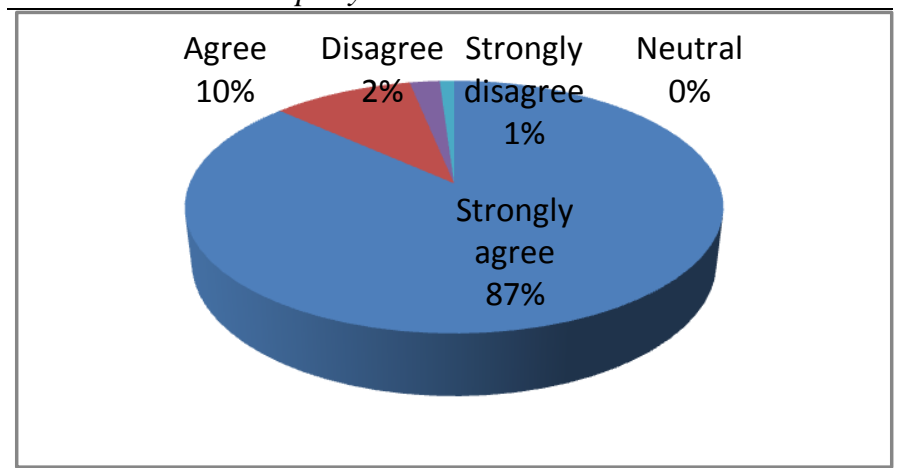

Figure 5: Company is a Great Place to Work

Sources: Compiled from survey of H-D respondents 
Interpretation: According to the sample selected $86.33 \%$ of the employees find the company as a great place to work in.

d. Quality of work/Life Balance

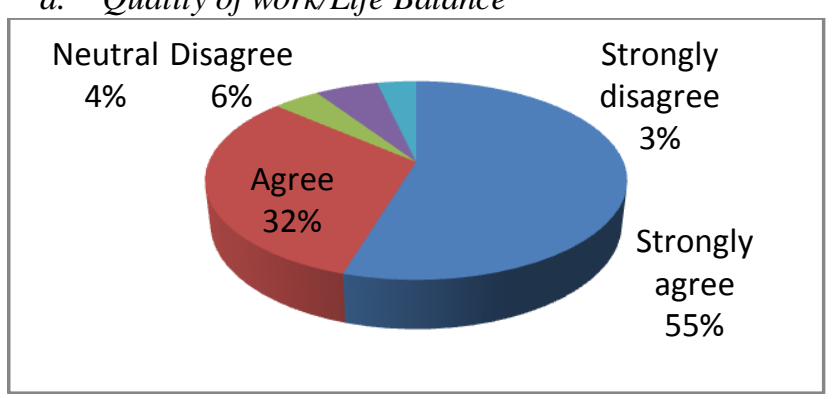

Figure 6: Good Work/Life Balance

Sources: Compiled from survey of H-D respondents

Interpretation: According to the sample studied $54.67 \%$ of the employees find good work/life balance.

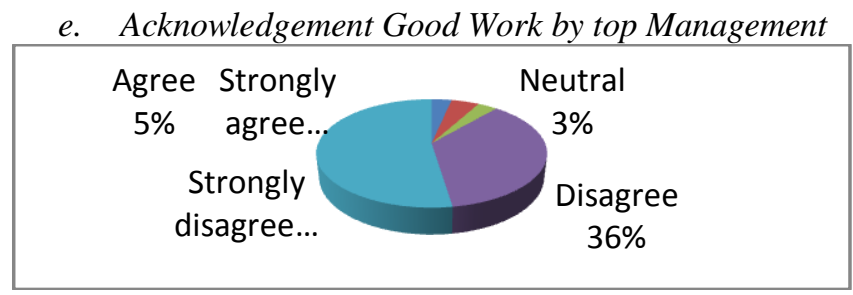

Figure 7: Acknowledgement for good work from top Management

Sources: Compiled from survey of H-D respondents

Interpretation: According to the sample only $1.43 \%$ of the people completely agree that the supervisor acknowledges their good work and a majority i.e. $56.11 \%$ strongly disagree the acknowledgement of the good work done by their supervisors.

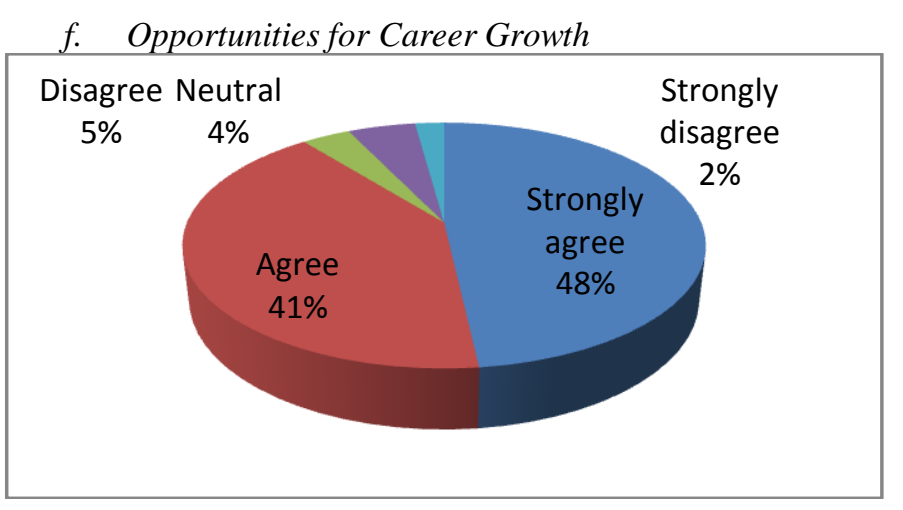

Figure 8: Organization provides Opportunities for career Growth

Sources: Compiled from survey of H-D respondents

Interpretation: According to the sample $48.2 \%$ of the employees strongly agree that the organization provides opportunities for career growth. g. The factors which Motivates most for Working at H-D.

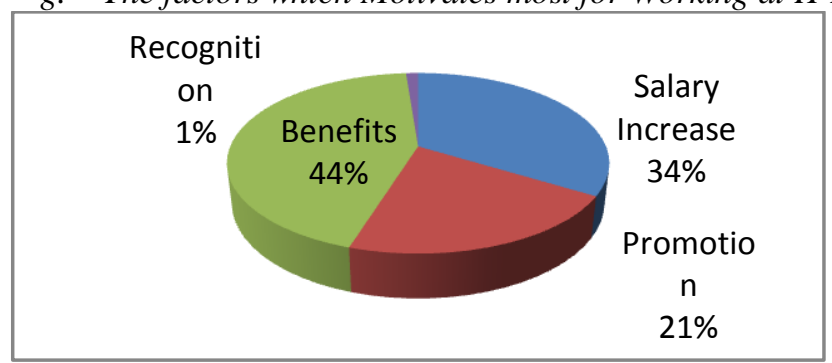

Figure 9: Factors which Motivates me Most for Work

Sources: Compiled from survey of H-D respondents

Interpretation: According to the sample studied $43.16 \%$ of the employees say that mostly the benefit provided by the company motivates them for work at H-D.

h. Employees Satisfied at Harley Davidson?

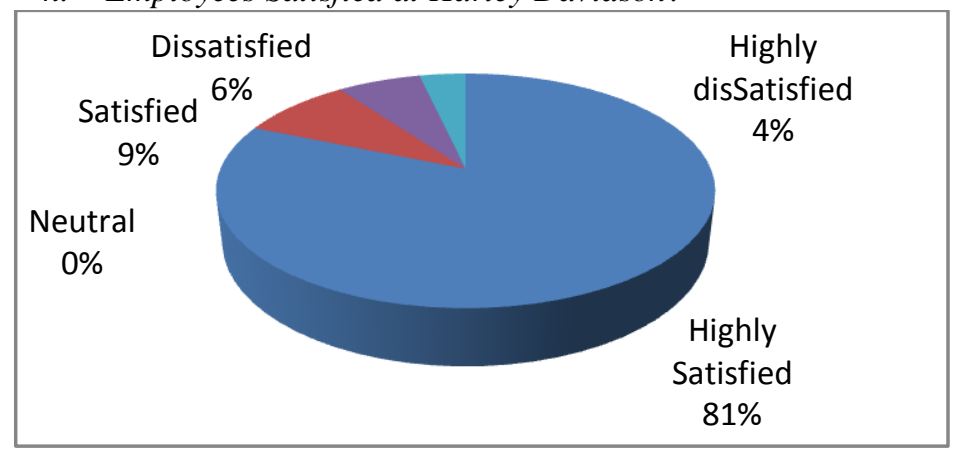

Figure 10: Satisfaction as an Employee of HD

Sources: Compiled from survey of H-D respondents

Interpretation: According to the sample studied $81.29 \%$ of the employees of H-D are satisfied to work at H-D.

i. Recommend this Company to Friends and Relatives

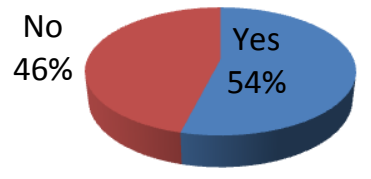

Figure 11: Recommending the Company to Family and Friends

Sources: Compiled from survey of H-D respondents

Interpretation: According to the sample 53.9\% of the employees would recommend the company to their family and friends.

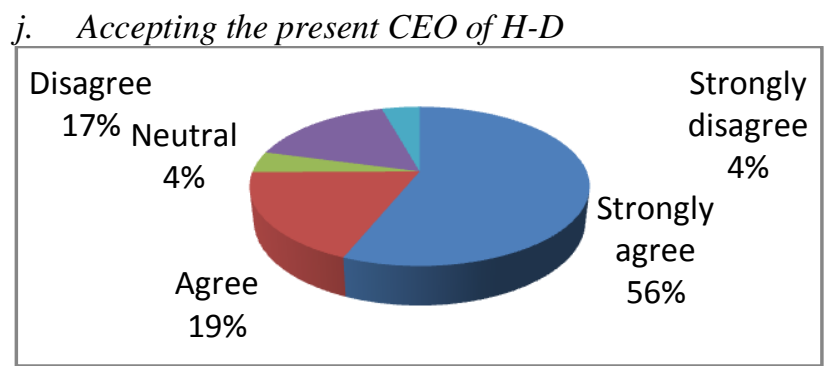

Figure 11: Accepting the present CEO 


\section{Sources: Compiled from survey of H-D respondents}

Interpretation: According to the sample $56.11 \%$ of the employees recommend Keith Wendell as the CEO of the company.

\section{TESTING OF HYPOTHESIS}

- Harley Davidson has its own brand image: In view of hypothesis 1 . We found that $95 \%$ responded the company is having strong brand personality, 93\% responded it gives a tough, dark and strong feeling, $92 \%$ responded that the products gave a feeling of Harley experience, $91 \%$ responded that the product gave a rugged appearance, $90 \%$ responded as giving the feeling of being rebellious and individual ,89\% responded it made them feel born free, $88 \%$ responded that it fulfills dreams and $80 \%$ response that it is outdoorsy. Hence we accept the null hypothesis $\left(\mathrm{H}_{0}\right)$ and reject the Alternate hypothesis $\left(\mathrm{H}_{0}\right)$.

- Friendly work culture helps in the company's growth: In view of hypothesis 2 we found $84.89 \%$ of the Harley-Davidson employees found the working environment to be very friendly. Hence we accept the null hypothesis $\left(\mathrm{H}_{0}\right)$ and reject the alternate hypothesis $\left(\mathrm{H}_{1}\right)$.

- Employee's recognition is essential by the Top Management: In view of hypothesis 3 we found $56.11 \%$ strongly disagree the acknowledgement of the good work done by their supervisors. Hence we accept the null Hypothesis $\left(\mathrm{H}_{0}\right)$ and reject the alternate Hypothesis $\left(\mathrm{H}_{0}\right)$.

\section{Findings AND SUGGestions}

From the primary and the secondary data by interviews of employees and customers and on-line questionnaires we came up with the following findings of the company. The findings highlighted the reaction of customers on the brand Image of the work/life balance, culture/values, compensation and benefits program, senior management and career opportunities at Harley Davidson Company.

The Findings are-

- Company has a brand image of its own and is very popular among the youth due to its strong brand personality, tough, dark, strong feeling,feeling of Harley experience, appealing rugged appearance, giving the feel of being rebellious and individual .Its speed agility gave a feeling of being born free. It fulfilled dream and was known for being outdoorsy.

- Company has a Good work culture

- Company provides Good Benefits

- Company has a friendly atmosphere at work.

- There is Good Work/Life Balance

- There is unfavorable union management relation

- The employees were not appraised for their work by the management

Finally I would like to put forth the strategies which would help to re-revive and keep up to the standard, quality, work culture, market competitiveness and better relationships with the upper management

\section{A. Advice to Management}

- Culture Shift: Management should engage the employee for being the catalyst to drive the new culture shift and take employees views in some matters.

- Organized Departments: Departments should be more organized for proper functioning.

- Include Training and Development Program: Management must help their employees to grow professionally and rationally as good human beings and thus be given proper training. They should be comprehensively trained in the core sector as required and also in specific problem-solving methods

- Employee Involvement Program: Management must be committed to Employee Involvement program and should have mutual trust among themselves and the management,

- Need Good Leaders: There is need for good leaders to inspire the company for growth and be focused on employee engagement.

\section{CONCLUSION}

Harley Davidson has a mark of its own in the market of automobiles. This research is an attempt to find the popularity of its brand, image and culture of H-D which has helped in the success of the Motorcycle Industry . From our findings we conclude that Harley Davidson has its own brand image ,a good work culture, good benefits for its employees, friendly atmosphere, and good work/life balance. We came to know that there are certain areas where the management should improve such as union management relationships and in appraising the employees for their work. We have also recommended certain strategies to be undertaken by HR for bringing changes in the organization such as taking the employees views on certain matters, organize departments well, helping the employees in their personal and professional growth by having Training and Development programs and employing inspiring leaders for the growth and development of the company. This article is an attempt to ' guide the future HR of High rising companies to look into their systems and develop the programs to ensure sustainability in business.

\section{REFERENCES}

[1] Barney ,J.(1991). Firm Resources and Sustained Competitive Advantage ,Journal of Management, 1 (17): 99-120

[2] Venkatraman ,N.,\& Ramanujam ,V.(1986). Measurement of Business Performance in Strategy Research: a

[3] Comparison Approaches. Academy of Management Review,11,801-814.

[4] Ricardo,R., \&Wade ,D.(2001). Corporate Performance Management: How to Build a Better Organization Through Measurement Driven Strategies Alignment. Butterworth Heinemann.

[5] Chien, M.H.(2004) A Study to Improve Organizational Performance. A View from SHRM. Journal of American Academy of Busines,Vol.4,1/2;p289.

[6] H ATCH , M ARY J O AND M AJKEN S CHULTZ (2003), "Bringing the Corporation into Corporate Branding", European Journal of Marketing, 37 (7/8), 1041-1064.

[7] Aaker, D. A. (2004). Brand portfolio strategy. New York: The Free Press 
[8] S CHULTZ, M AJKEN AND M ARY J O H ATCH (2003), "The Cycles of Corporate Branding: The Case of the LEGO Company", California Management Review, 46 (1), 6-26.

[9] A AKER , D AVID A. (2004a), Brand Portfolio Strategy. Creating Relevance, Differentiation, Energy, Leverage and Clarity. New York, Free Press.---- (2004b), "Leveraging the Corporate Brand" California Management Review, 46 (3), 6-18

[10] H ATCH , M ARY J O AND M AJKEN S CHULTZ (2003), "Bringing the Corporation into Corporate Branding",European Journal of Marketing, 37 (7/8), 1041-1064.

[11] Kilmann,R.,Saxton,M.J.,Serpa,R.(1985).Gaining Control of the Corporate Culture.San Francisco:Jossey-Bass.

[12] Deal,T.E,\&Kennedy A.(1982). Corporate Culture, The Rites and Rituals of Corporate Life. Reading: M.A:Addison Wesley

[13] Hofstede,C.(1980). Culture's Consequences: International Differences in Work-related Values. Veverly Hills,California: Sage

[14] W. G. Ouchi, Theory Z: How American Business Can Meet the Japanese Challenge (Reading, MA: Addison-Wesley, 1981), p. 41.

[15] . Martin, J. and Siehl, C. (1983). Organizaticnal culture and counter culture:an uneasy symbiosis. Organizational Dynamics, 12(autumn), pp. 52-64

[16] Reference: Adler, N.J. (1997) International dimensions of organizational behaviour, 3 rd ed.Cincinnati, Ohio, Shour-Western College Publishing. Source: Hillier, D. (2006) Communicating Health Risks to the Public. A Global Perspective.Gower Publishing Ltd. (p.23)

[17] Denison,D.R.(1990) Corporate Culture and Organizational Effectiveness New York: John Wiley and Sons.

[18] Cameron, K.S. and Quinn, R.E. (2011) Diagnosing and Changing Organisational Culture - Based on the Competin Values Framework, 3rd Edition, John Wiley and Sons, San Francisco, CA.

\section{Aftab Ara}

She was born at Rourkela, Odisha, India on 21.11.1976 .

Education Background: She is currently pursuing $\mathrm{PhD}$ in Management at Ravenshaw University,Cuttack ,Odisha from2013 to 2015.She has completed her Master of Business Administration in Human Resource from Indira Gandhi National Open University, New Delhi, India on 2011,graduated with first division Bachelor of Engineering(B.E) in Electronics and Telecommunication Engineering from Purushottam Institute of Engineering and Technology, Rourkela ,Orissa ,India on 2004,Completed Higher Secondary Education from Government College, Rourkela, India, Orissa on 1994 in first Division and Indian Certificate School Examination from Carmel Convent School, Rourkela, Orissa, India in 1992 in first Division.

She has worked as Lecturer in IT and Computing Department at Arab Open University, Hail, Saudi Arabia from Feb 2006 - April 2009(Part time) and May 2009-Jan 2012(Full Time)

and as Lecturerin Electronics and Telecommunications Department at Purushottam Institute of Engineering and Technology, Rourkela, Orissa, India from July 2004 - Feb 2005

She has also done her internship at (i) Steel Authority of India Limited during her engineering career on 2003 (ii) undertaken Projects at Software Training Parks of India on Visual basic, Java and Oracle and(iii) Undertaken MBA Project on Training and Development at Indfab Projects Pvt Limited .

Some of her Published research articles are "Employee Retention Strategy: A Case Study Of Saudi Oger Company, Saudi Arabia" Asia Pacific Journal of Marketing \& Management Review__ ISSN 2319-2836 Vol.3 (3), MARCH (2014) (with Dr Kishore .Kumar Das) and "Ict As A New Wave In Teaching And Learning Strategy -An Overview Of University Of Hail, Saudi Arabia"_Asia Pacific Journal of Marketing \& Management Review_ISSN 2319-2836 Vol.3 (3), MARCH (2014)(with Dr Kishore .Kumar Das)Her Research interests are in Strategic Planning and Implementation, International Business ,Multinational Strategy and Structure, Technology and Knowledge Management, ICT ,Organizational Development etc

(E-mail:ara.aftab@gmail.com)

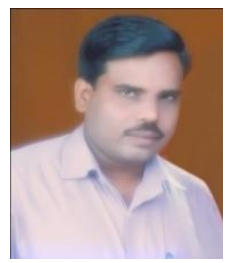

Dr. Kishore Kumar Das (Born at Bhadrak district of Odisha, India on $24^{\text {th }}$ June 1971) is now working as Associate Professor and Head, Department of Commerce and Management, School of Commerce and Management Studies, Ravenshaw University, Cuttack, Odisha. The core area of his research is commerce and management, he would like to continue his research work in the same area and explore the various dimensions and issues involved in the area of commerce and management in the execution of business decisions. His academic background includes: M. Com. (Finance \& Accounting) (1993) Utkal University, M. Phil. (Finance) (1999) Utkal University, Ph. D. (Finance) (2008) Fakir Mohan University, L.L.B. (Taxation and Business Law) (1996) Utkal University, P.G.D. in Financial Management (1998) I.G. N. O. University and P.G.D. in Management (2012) I.G. N. O. University

He holds the different important positions such as: Head: Department of Commerce \& Department of Management, School of Commerce and Management Studies, Ravenshaw University, Cuttack, Odisha. (01.06.2013 to till date), Associate Professor in Commerce \& Business Management, department of Commerce, School of Commerce and Management Studies, Ravenshaw University, Cuttack, Odisha. (15.01.2013 to till date), Assistant Professor of Business Management, Department of Commerce, School of Commerce and Management Studies, Ravenshaw University, Cuttack, Odisha.(04.05.2010 to 15.01.2013), Lecturer in Commerce, Government Autonomous College, Bhawanipatna, Odisha \& Counselor-cum-Guest faculty in Commerce and Management, I.G.N.O.U Study Centre, Government Autonomous College, Bhawanipatna, Odisha (19.02.2001 to 03.05.2010) and Dy. Officer (Finance) in the Department of Fund Resource Management (FRM) of M/s J. K. Synthetics Limited, New Delhi, Kota and Jhalawar (Rajasthan) (01.01.1996-12.10.1998). The other important responsibilities and position he occupies includes- Member: University Research Advisory Committee, Board of Studies in Commerce, Board of Studies in Management, Academic Council, University Price Negotiation Committee, University Internal Audit, Convenor: University Unserviceable Article Write off Committee, Dy. Coordinator: U.G.C. Career Oriented Course, Dy. Controller of Examinations, etc.

He has awarded with different awards and honors: Associate Fellow: Indian Institute of Advance Studies, Rashtrapati Nivas, Shimla, Associate Editor: The Orissa Journal of Commerce, Executive Member: Orissa Commerce Association, Best Research Paper Award: All Odisha Commerce Conference-2014 and Secure First position in M. Phil Examination

$\mathrm{He}$ is the recognised guide in the subject of commerce and management of different universities such as Ravenshaw University, Utkal University, F.M. University and Sambalpur University. He holds life membership of different accredited bodies includes- Indian Commerce Association, International Association of Academicians and Researchers (INAAR), Odisha Commerce Association, O.G.C.T. Association and RUT Association. The core area of his research is commerce and management. Four Ph. D's \& twelve M. Phil. Scholars have successfully completed their degree under his active supervision. Six Ph. D. \& three M. Phil. scholars continuing their research work in his guidance. The current topics of research includes- Compensation Management Practices of Software Industries:-A Case Study of Odisha, Equity Finance in the Indian Corporate Sector: An Empirical Analysis, Working capital management in the Indian Iron and Steel Industry: An indepth study, Credit risk management in Indian private sector banks: An indepth Analysis, and Capital Structure in the Indian Corporate sector: an indepth study

He has authored six text books and about eighty publications in different international, national and academic journals in repute. Some of important publications include- Quantitative Techniques, Himalaya Publication House, Mumbai, Managerial Financial Accounting, Himalaya Publication House, Mumbai, Business Mathematics \& Statistics, Himalaya Publication House, Mumbai, etc. His International publications includes Das, K.K. \& Ara, A. (2014), "Employee Retention Strategy: A case Study of Saudi Oger Company, Saudi Arabia", Vol.3, March, 2014. Asia Pacific Journal of Marketing \& Management Review (APJMMR) pp. 45-60, ISSN - 2319-2836. Das, K.K. \& Ara, A. (2014), "ICT as a new wave in Teaching and Learning Strategy -An Overview of University of Hail, Saudi Arabia", Vol.3, March, 2014. Asia Pacific Journal of Marketing \& Management Review (APJMMR) pp. 61-104, ISSN - 2319-2836. Das, K.K. \& Pande, S.P. (2014), "Study and Analysis of the Impact of Trade Unions and the efficiency of less performing workforce in manufacturing industries", Vol-III, Issue 5(I), January, 2014. International Journal of Business, Management \& Social Sciences (IJBMSS) pp. 01-05, ISSN - 2249-7463. Das, K.K. \& Pande, S.P. (2013), "Impact of existence of less performing Human resources on Quality and productivity in the manufacturing industries", Vol-2, October- December, 2013. International Journal of Marketing, Financial Services \& Management Research, pp-72-79, ISSN: 2277-6788. Das, K.K., (2013), "Non Fund based Income in Indian Banking Sector: An In-depth Study", Vol-3, No-2 November 2013, 
Kushagra International Management Review (A bi-annual International Journal) pp. 38-63 ISSN - 2250-0960. Das, K.K., (2013), "Management of Long Term Fund in SME Corporate Sector: A Case Study of India" Vol-3, No-1 May 2013. Kushagra International Management Review (A bi-annual International Journal) pp. 84-93 ISSN - 2250-0960. Das, K.K., (2012), "Long-Term Debt: A Strategical Consideration In Indian Corporate Sector", Volume- I, Issue-II, September 2012, Journal of Business Management, Commerce \& Research(An International Referred Quarterly Business Research Journal) pp. 43-53 (ISSN 2278-5280)(Print) Das, K.K., (2012), "Strategical management of equity funds in corporate sector of India: an empirical study", Vol-2, No-2 November 2012, Kushagra International Management Review (A bi-annual International Journal) pp. 84-93 ISSN 2250-0960. Important publication in national journals includes Das, K.K. \& Pande, S.P. (2014), "Study of the impact of Industrial relation on Quality of Work life of the Workforce in the Public Sector", Vol-IV, Issue:1, January 2014.Vishawkarma Business Review (VBR), A bi annual Peer Reviewed Research Journal of VIM, Pune, pp. 87-92, ISSN - 2229-6514(print), 22308237 (Online). Das, K.K., (2013), "Direct Tax Code (DTC): A Relief to the Taxpayer" IPSAR Management Review, Volume-13, No.1, January-June 2013, ISSN 0976-2027. Das, K.K., (2013), "Debt Securitization in IndiaRegulatory Issues and Challenges" proceedings of the A.I.C.T.E. \& Ministry of HRD. Government of India Sponsored National Seminar on "Strategic Measures for Economic Sustainability and Innovations", KIIMS, Cuttack. $18^{\text {th }}$ May 2013, Page 50-56, ISBN: 978-93-5097696-8. Das, K.K., (2013), "Debt Finance in the Small Corporate Sector in India: A Strategical Need", Volume-13, No.-2, April- June, 2013, SIDDHANT: A Journal of Decision Making,(Indian Journals.com), Print - ISSN: 2231-0649, Online - ISSN: 2231 - 0657. Das, K.K., (2012), "Debt Finance: A Conceptual Study in the Indian Corporate Sector", Volume-12, No.-3, July- September 2012, SIDDHANT: A Journal of Decision Making,(Indian Journals.com) pp. 207219, Print - ISSN: 2231-0649, Online - ISSN: 2231 - 0657. Das, K.K., (2012) "Role of Information and Communication technology(ICT) in accelerating financial inclusion", The Odisha Journal of Commerce, Volume XXXIII December 2012, Number- 1 \& 2, pp.- 201-207, ISSN 0974-8482. Das, K.K., (2011) "A study of religious aspect of the entrepreneurial ethics" IPSAR Management Review, Volume-11, No.1, January-June 2011,pp.-1019, ISSN 0976-2027.

Das, K.K., (2009) \& Jena A.B. "Ethics \& the Entrepreneur- An Overview" ANVESA: An Interdisciplinary Journal, Volume 4. Issue $1 \& 2$. 2009, page 120-127, ISSN 0974-715x.

He may be contacted at drkkdasru@gmail.com. 